\title{
RESEARCH USING METAL DETECTORS AT THE BATTLEFIELD OF MUHI Community Archaeology, Battlefield Investigation and Related Methodological Issues
}

József LaszlovszkY ${ }^{1}-$ Tibor ÁKos Rácz ${ }^{2}$

Hungarian Archaeology Vol. 9 (2020), Issue 4, pp. 71-81. doi: https://doi.org/10.36338/ha.2020.4.7

The defeat of the Hungarian forces at the battle of Muhi was a key historical episode, since it opened the country to the Mongol invasion. This event had complex consequences that have not yet been fully clarified regarding the further development of Hungarian society and its economy. The identification of the site of the battlefield has contributed to the better understanding of the events of 11 April 1241. The known course of events has been established through subjective written sources that were often based on indirect information. The identification of certain elements of the battle can provide new information, since it may be possible to reconstruct the tactical options provided to the leadership of the Hungarian and Mongolian forces by the geographical circumstances and how the location influenced the outcome of the battle. The research on the battlefield of Muhi gained momentum through the assistance of volunteers associated with a number of museums using metal detectors. In this article, we investigate the following question: what kind of opportunities does community archaeology provide in the interdisciplinary investigation of an Árpád Period (1000-1301) battlefield, and what kind of practical and methodological problems face research using metal detectors? $?^{3}$

A few years ago, a growing number of archaeological finds made it worthwhile to examine the archaeological remains of the Mongol invasion, and more precisely the battle of Muhi (Laszlovszky, Pow \& PuszTAI 2016). 'The Mongol Invasion of Hungary and its Eurasian Context' project began in 2018 through the collaboration of several Hungarian researchers and institutions and with the support of the Hungarian National Research, Development and Innovation Office. The first results of the project contributed to placing the general context of the Mongol invasion under a new light (LASZLovszKY et al. 2018) and re-examined in detail a topographical question connected to the battle of Muhi (LAszLovszKy \& Pow 2019). This multi-year research program summarizes these new results from the growing number of archaeological finds connected to the Mongol Invasion as well, formulating the reasons for this fateful episode in Hungarian history, the course of events and the consequences. We employed numerous new research technologies and archaeological approaches during the examinations, thus one of our aims is to publish our methodological observations. We developed a complex methodology in the examination of the battlefield based on the general methodology of battlefield and the conflict archaeology as well as on the past and recent results of Hungarian battlefield archaeology (B. SzABó et al. 2020). The latter research trend does not only concentrate on the battle as a single event, but analyses its antecedents and consequences. In this respect, one of the most important changes compared to earlier research is the inclusion of volunteer amateurs using metal detectors in the examinations, which has produced several results in the investigation of the battle of Mohács (SzABÓ et al. 2016). Since community archaeology does not have as significant a history in Hungary as it does in other some countries (RÁCZ 2019) and the regulations, policies and practice of research with metal detectors have changed recently (V. SZABÓ 2013; ÚJHELYI 2017; RÁCZ 2017), it is important to summarize the methodological problems associated with this approach.

\footnotetext{
Central European University, Department of Medieval Studies, Cultural Heritage Studies Program. Email: 1aszlovj@ceu.edu

2 Ferenczy Múzeumi Centrum. E-mail: racz.tibor.akos@gmail.com

3 This article was provided support by the Hungarian National Research, Development and Innovation Office in the context of 'The Mongol Invasion of Hungary and its Eurasian Context' project (K 128880).
} 


\section{BATTLEFIELD RESEARCH, CONFLICT ARCHAEOLOGY AND THE BATTLE OF MUHI}

The precise sites of the particular events in the battle of Muhi (B. SzABó 2019) are not known, and the course of the Sajó River, where the Hungarian and Mongolian armies were deployed on opposite banks, may have changed since the Árpád Period, making identification more difficult. Additionally, environmental changes in the area where the battle took place have transformed the territory significantly. There have been attempts in Hungary since the 19th century to identify the location of the battlefield of Muhi with the help of known medieval written sources, but the identification of its precise site was not possible (LAszLOVSZKY 2013, 453). The search for unequivocal archaeological phenomena - as in the case of the battle of Mohács, where excavated mass graves were clear signs of that event - was unsuccessful. In accordance with international research (Freeman \& Pollard 2001; Sutherland \& Holst 2005; Pollard \& Banks 2010; Scott \& McFeaters 2011), it is worthwhile to move forward by both employing applied research methods and formulating research frameworks concentrating on the investigation of the entire theatre of war in addition to the concrete battlefield sites. The broader understanding of the theatre of war includes the camps, the areas where the armies were deployed, the location of the engagement, the paths of retreat, and the mass graves. The new methodological approaches connected to the investigation of battlefields and the approach introduced by conflict archaeology widen temporal frames, since the focus is not only on the battle itself, but on its antecedents and its consequences. In this sense, research on the battlefield of Muhi can be successful only through the interpretation of the entire Mongol Invasion.

Sites of medieval armed conflicts can be studied most effectively using archaeological methods. Field surveys, site surveys using instrumentation (for example geophysical), and excavations make it possible to understand the material remains. Battlefields are archaeological sites in a same way as former settlements or cemeteries, but due to their nature, they are more endangered by cultivation and the illegal use of metal detectors. The Archaeological Database of the Hungarian National Museum contains only one medieval battlefield, some sites of the battlefield of Mohács, and so only these sites enjoy a certain amount of protection. By comparison, there are 43 battlefield sites on the National Heritage List of England, which is also on a small portion of the total locations of conflict (Sutherland \& Holst 2005, 37; Pollard \& Banks 2010, 5-6). There is very little certain knowledge about the geographical conditions of medieval battlefields, and while archaeological research has been working on the identification and excavation of these types of sites for a long time, research on battlefields has been flourishing recently due to the use of metal detectors.

The strategic considerations behind the choice for the location of a theatre of battle are different than those for the settlement network of that period. The course of a conflict and the related events usually occur quickly, the duration for the formation of archaeological phenomena and the possible accumulation of finds is short, and thus their identification at sites, the sampling strategies, and the interpretation of dates require unorthodox archaeological methods. At the same time, the spread of firearms provides different opportunities for battlefield researchers, and this is even more so in the case of battles fought between regular armies. These factors significantly increased the number of metal finds and objects that were not collected, and thus remained at the battlefield. A good example of this is another fateful battle of Hungarian history, and the most recent research in the field is significantly based on this (PoLGÁR 2019). Since a medieval armed conflict does not produce classic archaeological features, the remains that exist are of paramount importance. It is extremely important to record their geographical coordinates and additional related information, and then interpret this on maps. This is because their relationships to each other and intensity provide a pattern that helps to make conclusions about the course of events. This methodological issue is also important in the identification of battlefield sites from earlier historical periods, but in the case of prehistorical sites, written sources do not even provide assistance (V. SzABó et al. 2014). With all this in mind, an object that seems insignificant at the moment of discovery may become relevant in the subsequent evaluation. In other cases, the exact spatial location and dispersion of particular types of objects (arrowheads or ammunition) that may emerge in great numbers can provide indications about the course of the military event. These types of investigations together with archaeological results and the analysis of weapon finds helped in the 
József Laszlovszky - Tibor Ákos Rácz • Research Using Metal Detectors at the Battlefield of Muhi

reconstruction of the course of the fight and the direction of the attack on the fortification of Czermno for example, which was a site of the Mongol Invasion in Eastern Europe (KuŚNIERZ 2005). Similarly, the typological analysis of arrowheads, spatial location of other weapon finds, study of geographical conditions, and complex processing of different parts of fortifications aided in the interpretation of a location of fighting in Slovakia. This site was not connected to the Mongol invasion, but instead the fortifications were identified as the site of Central European battles that occurred a few decades later (FARKAŠ 2006, 2015). At the same time, battles that took place on extensive, flat areas require research over a larger area. The size of battlefields obviously depends on the number of participants, the composition of the troops, and the tactics employed, but these factors do not leave traces of similar intensity throughout the affected area.

The Mongols essentially chose the location of the battle of Muhi when they baited the Hungarian royal army towards their main forces. The Mongol military leadership thus had a greater opportunity to take strategic positions, and they most probably tried to ensure suitable conditions for their tactics, which were out of the ordinary for westerner soldiers. In other words, they did not prefer a location that was suitable for an open battle, but instead a field that allowed for cover, deceit, and unexpected advances. The proximity of the Sajó River and its surroundings with swamps and gallery forests fit this aim perfectly. The Hungarian written sources describe in great detail the main elements of the battle of Muhi, which happened along the banks of the Sajó (NÉGYesi 1997, B. SzABó 2019), but there were certainly innumerable peripheral events and additional locations for clashes. If a site is known, then destroyed villages, mass graves, and hidden collections of finds can be researched through excavation. The battle site was most probably surrounded by settlements that were destroyed, thus finds of coins, hoards, and deposits of iron objects and tools would be expected to be higher. The events of the battle itself did not disturb the ground, thus systematic research on the upper soil layer can be more effective than a full-area excavation or a geophysical investigation. The establishment of a medieval military camp presumably involves some earthwork, but its extent may have been minor (Sutherland \& Holst 2005, 21). The establishment of a wagon camp at the battle of Muhiwhich is known from the description of Thomas of Split, but was later doubted by some scholars - would not involve significant earthwork, since it was temporary by its nature. The Mongol hail of arrows could have left some archaeologically observable marks, and if the wagon camp was actually burned, some iron components could have survived on the site and may have landed up in the ground, but there is little chance for their unequivocal identification. We assume that they picked up or systematically collected the larger iron objects (primarily the weapons) right after the battle or while they were still visible on the ground. The paths of retreat may have partially coincided with the road network of the period, where other lost objects of travellers - wagon parts, nails, wheel mounts, trappings, etc. - may also remain. Based on a fragment of armour that remained in a pit-house in Hejökeresztúr (Wolf 2014), we expect other finds indicating the scattered equipment of Hungarian nobles. Locating the mass graves would be of key importance, because the deceased were most probably not transported far from the battlefield (SuTHERLAND \& Holst 2005, 18). One of the very first phases of research on the battle of Muhi was also connected to a possible mass grave (at Muhi Field), but this turned out to be the churchyard cemetery of medieval Mohi (Muhi).

In the absence of constructed campsites and other defensive installations, the metal finds are the most identifiable material remains from the battle of Muhi. Thus, the scattered remains from that time must be found and filtered out from waste metal that has accumulated since. The expected number of finds cannot be compared to the remnants of modern warfare or late medieval metal materials. So far, there has not been much success in identifying the exact locations of medieval battles or combat in the territory of medieval Hungary. There is a Transylvanian archaeological site near Brânkoveneşti, Romania, where the location of a medieval military event was researched on the basis of scattered metal finds, but the lack of written sources makes it impossible to identify the battle (GYÖRFI 2012). In this case, the typology of the particular weapons, such as the arrowheads and the pieces of armour, helped those who processed the finds to determine the age and nature of the event. Thus, we can rely on general methodological parallels and foreign sites of combat with similar military technology in the research on the battlefield of Muhi. The battle of Muhi occurred before the appearance of firearms, which greatly reduces the amount of metal ammunition connected to the conflict. A late medieval 
József Laszlovszky - Tibor Ákos Rácz • Research Using Metal Detectors at the Battlefield of Muhi

or modern battle fundamentally results in metal finds of a different nature (POLLARD \& BANKS 2010, 34-35; FERGUSON 2012, 22-25). At the same time, items of clothing typical of uniforms related to the appearance of regular armies (such as uniform buttons) cannot be expected. It is well known that weapons and the recyclable metal objects were collected after battles, so it is usually only small objects that escaped notice and were left at the site. With all this in mind, the most important indicators for the location of the battle of Muhi must be arrowheads. Items of clothing and broken off pieces of armour, as well as jewellery, coins, horse tack, or weapons in fortunate cases can perhaps be expected to a smaller extent.

\section{COMMUNITY ARCHAEOLOGY IN BATTLEFIELD RESEARCH}

The site identification methods that were used in the research on the battlefield of Muhi were developed through both preliminary considerations and practical experience. The basis of the field research is a combination of the use of all available technical equipment (LiDAR, drones, ground scanning lasers, aerial photography, etc.), a great number of people using metal detectors, and research into local history and charters. To reconstruct the events of the battle of Muhi, it is also important to understand the medieval settlement network, so our aim is to identify the medieval network of settlements and roads as well. In addition to examining documentary sources, field research is the best way to achieve this. Performing systematic research on an area of $150-200 \mathrm{~km}^{2}$ is very difficult, and almost impossible. Large areas can be excluded through an examination of the data on historical geography and local history, while several potential locations can be identified preliminarily. However, finding traces of the battle or eliminating negative areas from consideration is only possible through field surveys, which are more effective with metal detectors. The professional use of metal detectors makes it possible to reconstruct the tiniest details of a conflict (Scott, Fox, ConNOR \& HARMON 1989).

The chance of discovering the relatively small amount of finds connected to the battle is increased by having a great number of people using metal detectors, in spite of the logistical challenges. One main reason for this is the fact, that most of the volunteers with metal detectors have an active interest in military history. Many have been attracted to archaeology through the collection of relics from the world wars (SzABÓ et al. 2016). Therefore, it is relatively easy to recruit volunteers for battlefield research. The general renown of the battle of Muhi and the importance of the associated historical events definitely serve as a call to action for participation in research like this. 70-80 volunteers with metal detectors join the research on the battlefield on each occasion they are gathered (Fig. 1). ${ }^{4}$ The organization of the great number of volunteers

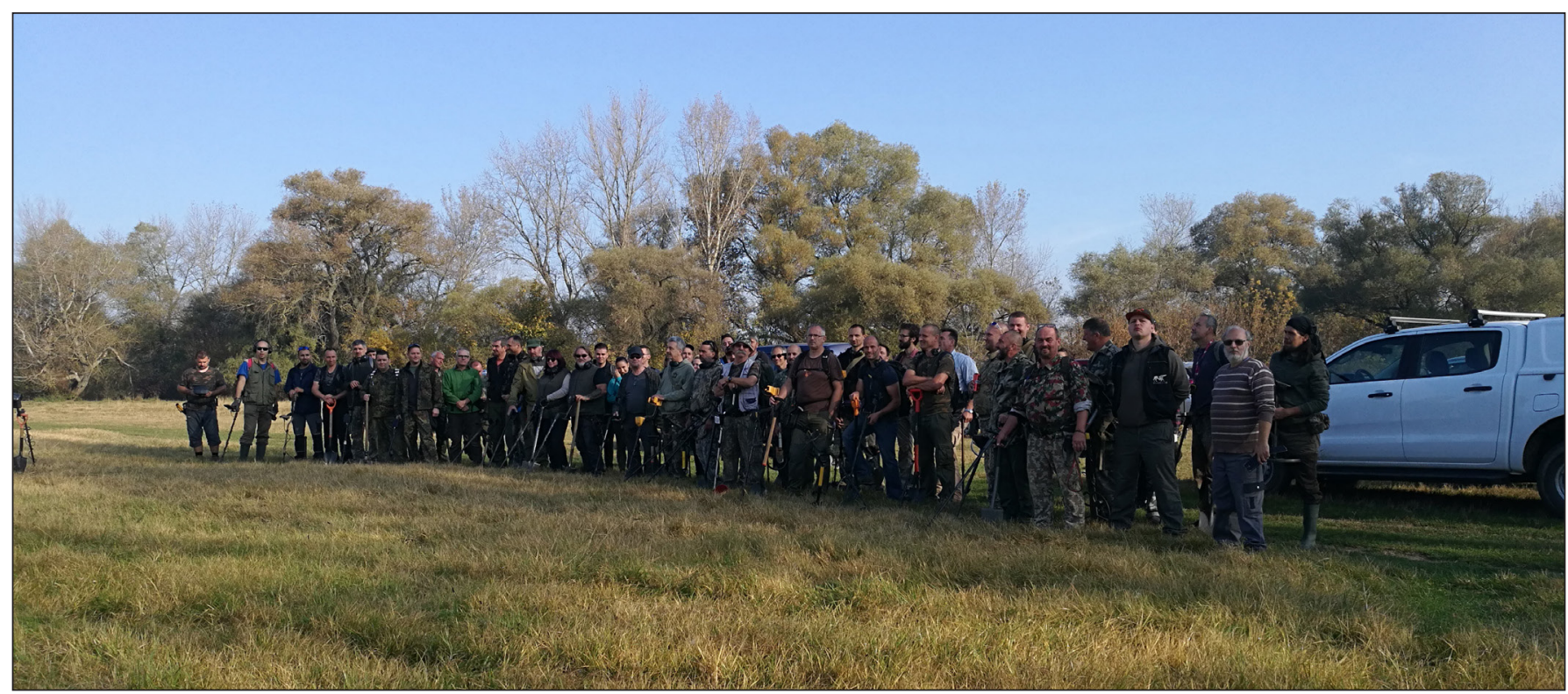

Fig. 1. Volunteers during a weekend survey in Ónod (photo by T. Á. Rácz)

4 Individuals join the work with the help of the Közösségi Régészeti Egyesület [Community Archaeology Association] and the Herman Ottó Museum of Miskolc. 


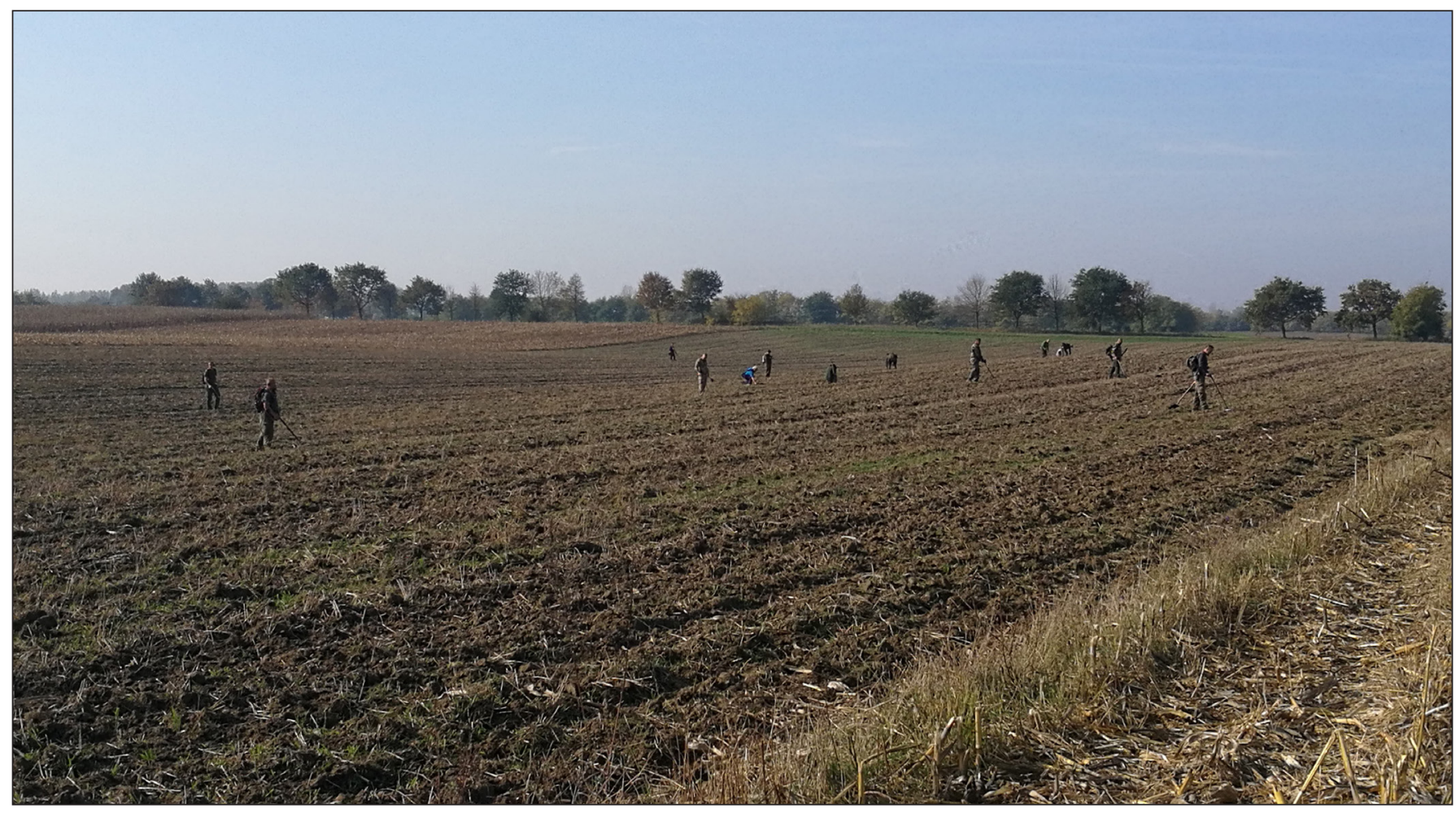

Fig. 2. Metal detectorist volunteers moving in a broad line, surveying an identified site of the battle (photo by T. Á. Rácz)

as well as the determination of the concrete aims of the research and techniques to be employed requires a significant amount of preparatory work. It is also necessary to include other related programs. Within the framework of the project, we teach the participants about the work processes that build upon one another, the scientific issues, and the methodology employed using a series of productions entitled "A tatárjárásról sok szemmel [About the Mongol Invasion from Different Perspectives]". This contributes to the development of a genuine partnership (for details, see the Tatárjárás 1241 [Mongol Invasion 1241] project website). The presentations and programs defining and introducing the materials related to the fieldwork are prepared especially for the participating volunteers, and usually precede or follow the fieldwork. ${ }^{5}$ In successful community archaeology projects, such as those in Scotland, volunteers with metal detectors are utilized in a similar way, but the local community is usually involved in the battlefield research as well (FERGUSON 2012).

For the identification of sites and preliminary orientation, research conducted in a browsing manner is expedient because a larger surface area can be covered in shorter time. In this case, the group moves in a broad line, utilizing its size to cover large areas of riverbanks or extensive agricultural plains (Fig. 2). Once the first promising metal finds are detected, we switch to systematic surveying, moving in denser, more orderly rows to achieve full coverage. There are particular characteristics of both techniques. No matter how boring or uninteresting it is, the volunteers must dig up the iron objects because they provide the most information about pre-firearm conflicts. Since modern "metal pollution" also mostly appears as smaller iron finds (nails, screws, machine parts), we have to be prepared for many finds that are not archaeologically relevant. In some cases, many small undistinctive finds turn up (such as tiny arrowheads), which in their fragmented forms are hard to differentiate from the tiny iron objects of later periods (fragments of tiny, forged nails). This needs to be particularly emphasized in the preparatory/introductory presentation or at the discussion of material identification when the finds are shown, because otherwise these finds may not reach the "stimulus threshold" of some of the volunteers (Fig. 3). The research on the battlefield of Bennington, which took place under controlled circumstances, is a good example of this (ESPENSHADE 2019).

There is no generally accepted methodology in Hungary for this type of research using metal detectors.

József Tarnóczi, the mayor of Ónod, has provided a room suitable for the presentations on the weekends when the field surveys of the battlefield of Muhi take place. 


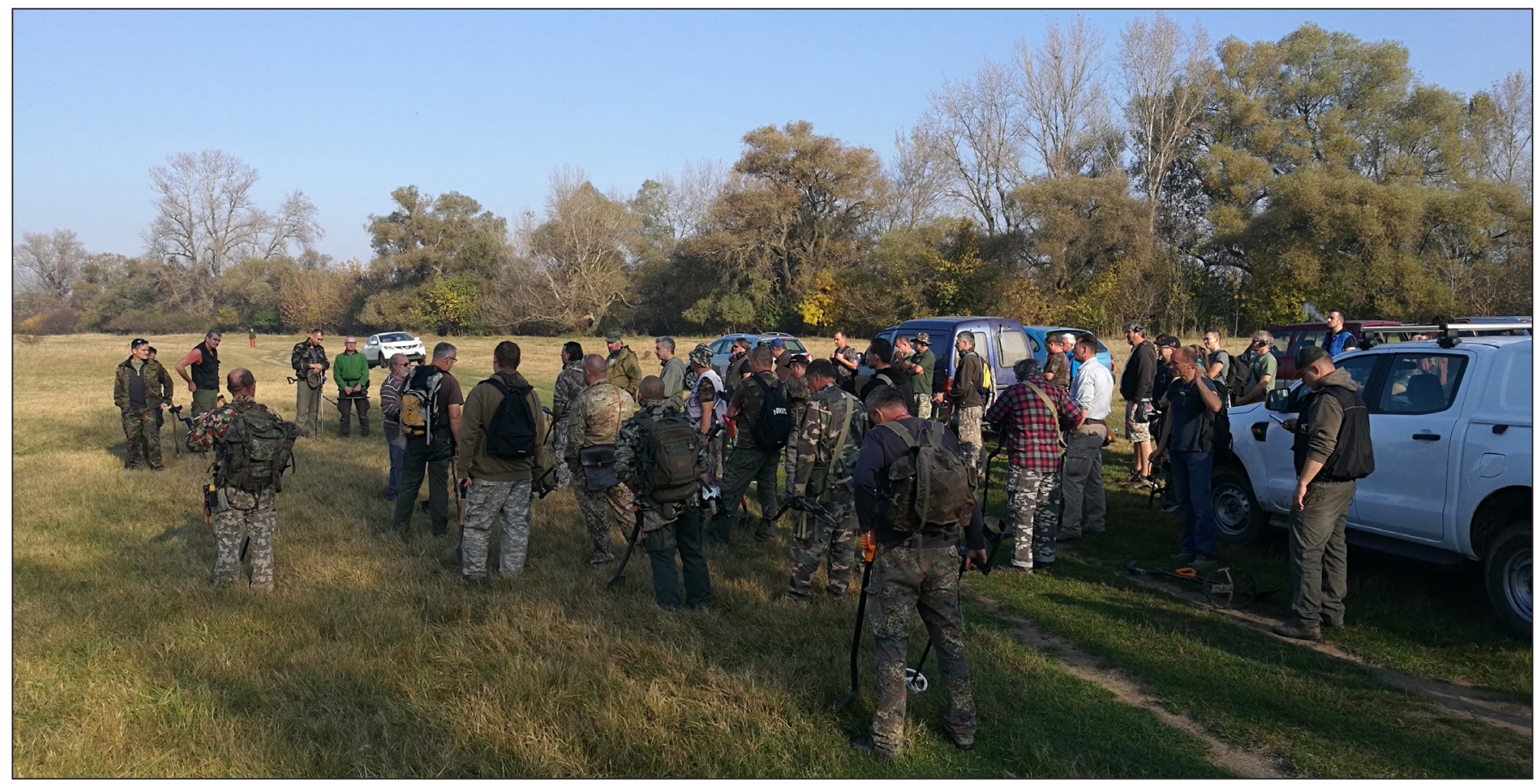

Fig. 3. Briefing before the survey (photo by T. Á. Rácz)

However, the need for a general protocol has been proposed at lively professional forums. The overall observations of the experiences at the battlefield of Muhi as well as at other locations is no substitute for this, but provides some illumination. Fieldwork with metal detectors that is systematic and performed in two directions at right angles to one another particularly enhances efficiency and increases the number of finds. The volunteers tend to follow their own "instincts" rather than the methodology of archaeology. In spite of repeated briefings, the organized row breaks down frequently and the tempo becomes uneven. A rise in elevation or the banks of a stream attract more of the participants and thus they are usually more thoroughly covered than uninteresting slopes. The individual methods and abilities of the volunteers (equipment settings, speed of movement, experience) also influence the uniformity of the recorded data. This is well illustrated by GPS tracking of individual volunteers, as has been observed in research on other major medieval battlefields, such as the inspection of the Grünwald battlefield in Poland (NowAKowsKi 2014; 2015; 2016; 2017). It is possible to skim over the site of a small skirmish without detecting anything even when paying concentrated attention. A metal detector is not a miracle device, and to discover an object depends largely on its position and the size of the surface covered by the detector. There may be cases where we may have discovered the location of a conflict, but we just do not realize it because the data found does not seem relevant at first glance. The ratios of different types of finds should also be monitored and the materials from each site should be re-evaluated after cleaning.

A fundamental dilemma arises as a result of this. Due to the size of the area studied, results can only be achieved through a large group of volunteers with metal detectors. However, due to the heterogeneous nature of such groups, there is a chance that we will skip over certain phenomena or that coverage will not be uniform when surveying an area. These problems are also well known in the analysis of the human factors of traditional archaeological field walks and the ability to perceive individual phenomena, but they increase exponentially in battlefield research. The only solution is continuous training, constant feedback and the organization of the individual volunteers involved in the work into a community, as suggested by Gábor Bakos (BAKOs 2020).

In addition to survey strategies, issues of the organization of the work are also a particular problem. Seventy-eighty people cannot be treated as a single group, and must be divided into smaller units with well-defined subtasks. A sufficient number of professional staff must also be provided. The work of each unit is supervised by an archaeologist and the documentation is assisted by archaeology students. Since the different organizations of the volunteers have developed different rules for how their members operate, 
József Laszlovszky - Tibor Ákos Rácz • Research Using Metal Detectors at the Battlefield of Muhi

the training must reflect these rules as well, while being dependant on their numbers and their previous training. At the same time, the research is not being conducted in a completely untouched area. Modern and contemporary agricultural cultivation has had an extraordinary impact on the historical landscape, a part of the research area is no longer accessible due to newly established quarry lakes and construction sites, and these interventions, surface features, and vegetation severely limit data collection. If one of the sites of the battle falls within the territory of a medieval settlement, its remains will have obviously "contaminated" the traces of the battle, and it will be difficult to differentiate them. Even more factors influence the results of research with metal detectors. The village of Hídvég, which presumably played a role in the events, had already been discovered and partially plundered by illegal looters using metal detectors before we arrived there. However, the less distinctive and "valuable" iron finds (tiny arrowheads) mentioned earlier do not attract illegal looters, so they are more likely to be found. There is a better chance to find these, especially if there was no medieval settlement in the given area. However, it is important in these cases that other small finds from the battlefield (medals, rings, mountings, etc.) should also unearthed, as they can be used to date and identify certain phases of the battle at locations such as these

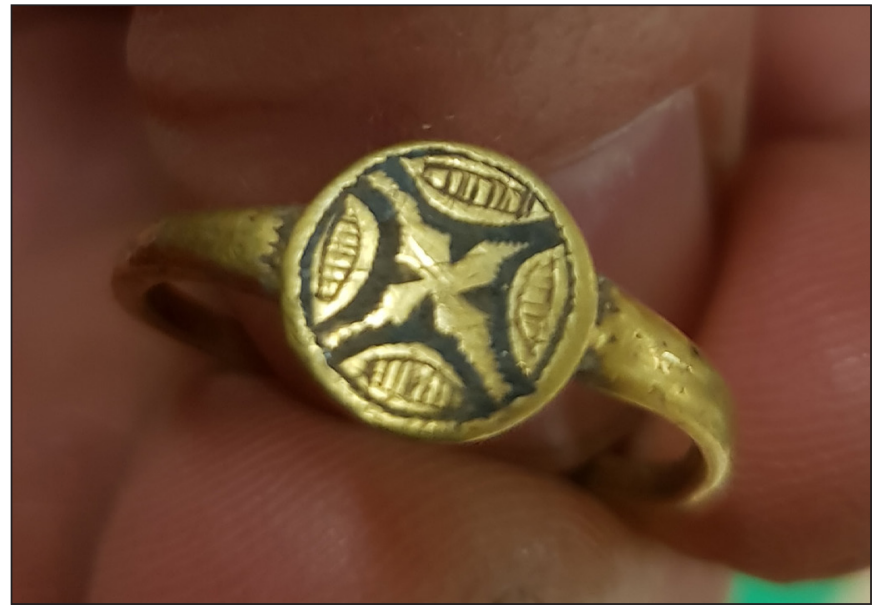

Fig. 4. Ring unearthed in the area of a destroyed medieval village, in the vicinity of the battlefield (photo by T. Tóth)

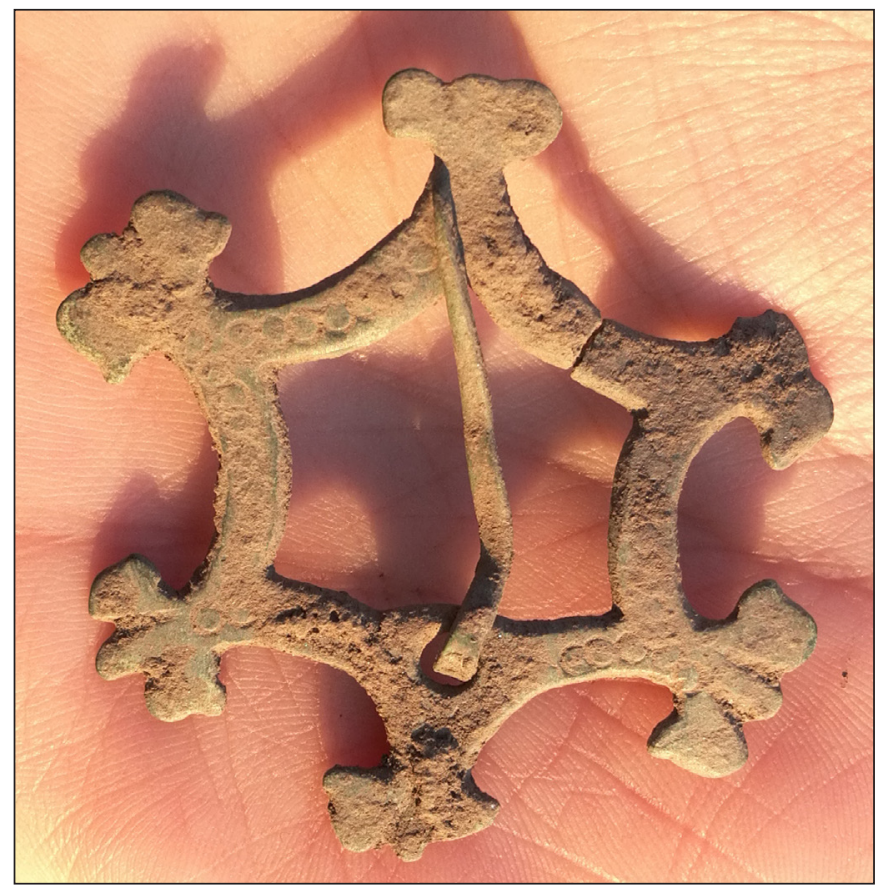

Fig. 6. Medieval bronze buckle found at an identified site of the battle (photo by T. Á. Rácz)

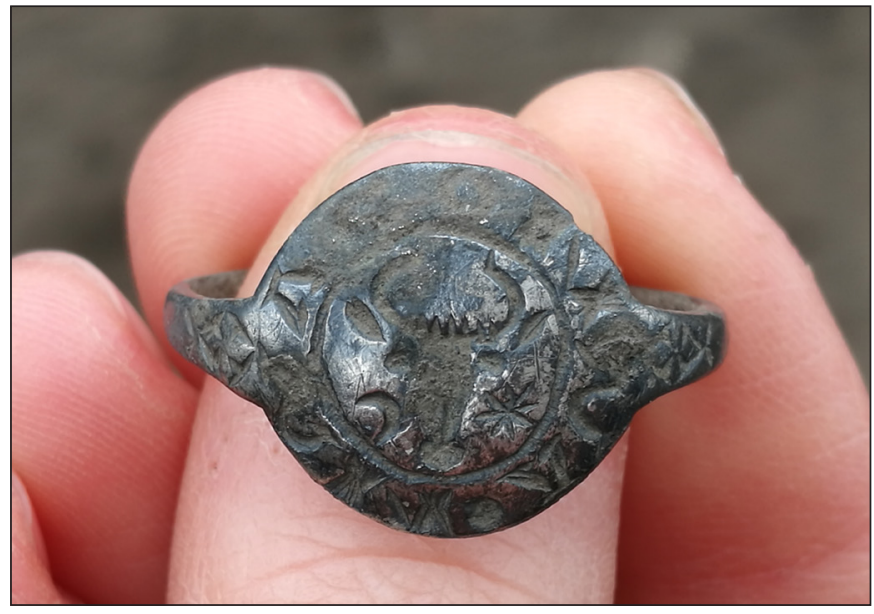

Fig. 5. Seal ring decorated with an ox's head, found at an identified site of the battle (photo by T. A. Rácz)

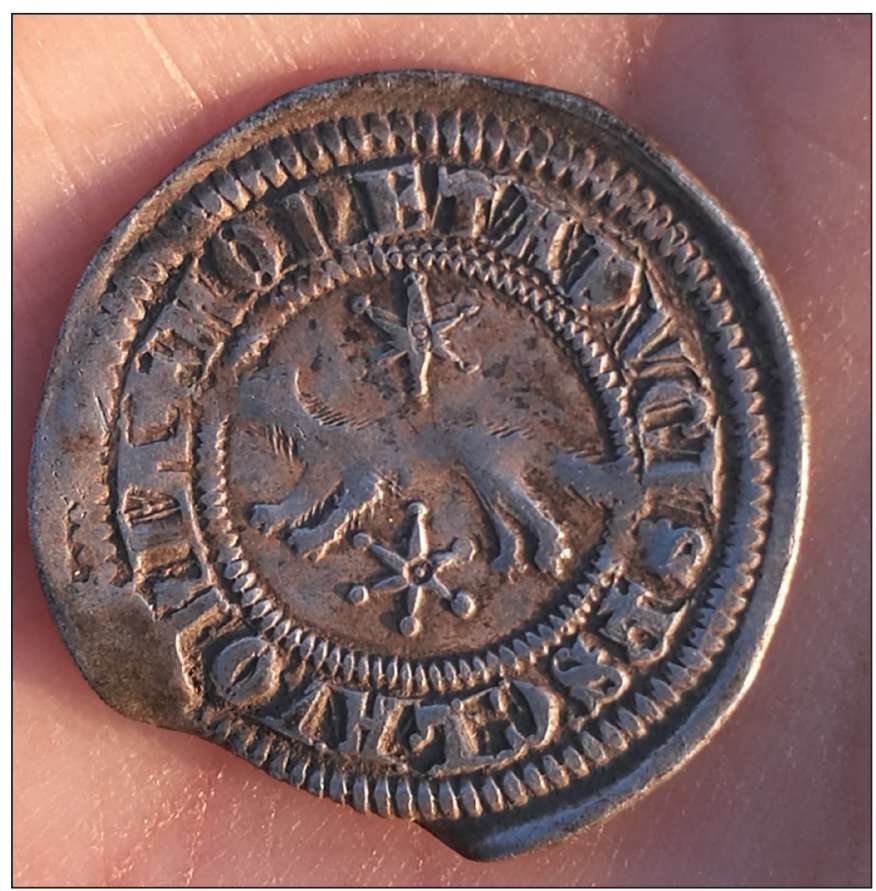

Fig. 7. Banovac coin found at an identified site of the battle (photo by T. Á. Rácz) 
József Laszlovszky - Tibor Ákos Rácz • Research Using Metal Detectors at the Battlefield of Muhi

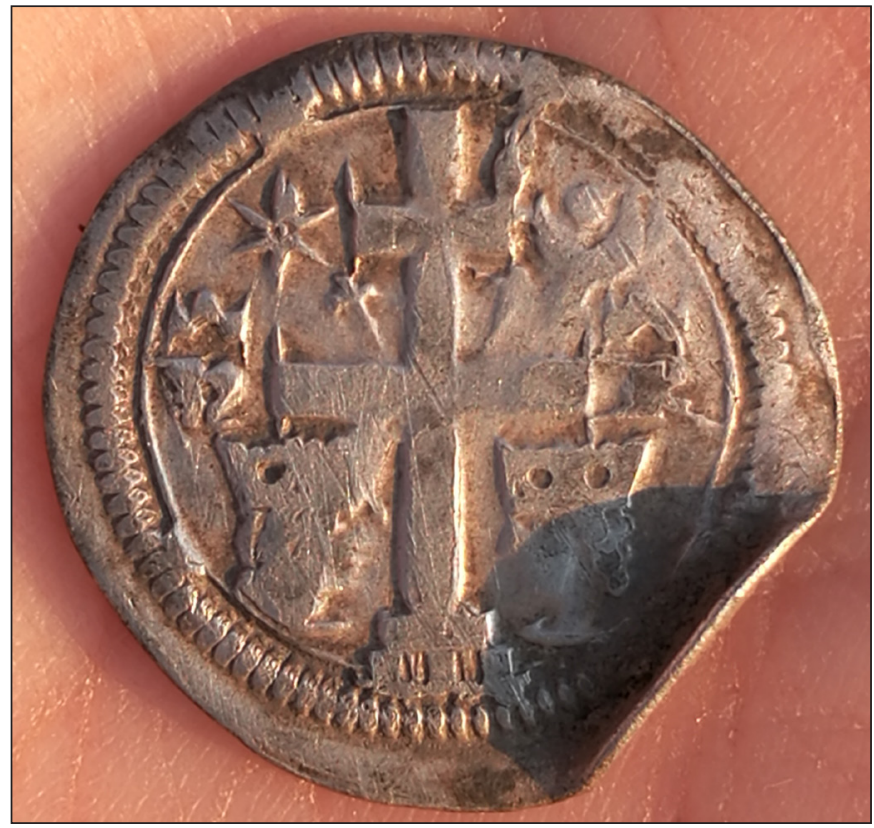

Fig. 8. Banovac coin found at an identified site of the battle (photo by T. Á. Rácz)

outside towns (Figs 4-10). In this respect, it may also be important to find bone arrowheads, since their use can be verified in the Mongol armies and they are already known from other Hungarian sites (Rosta 2018, 187). At the same time, we can hardly expect them to appear during field surveys, as they are very difficult to spot, and research with metal detectors does not help to find them either.

The battle of Muhi occupies a special place in Hungarian national memory, and a national memorial site has been established in connection with the battlefield. A monument, dreamed up by the architect György Vadász and the sculptor Sándor Kiss, is a shocking work of art that reminds visitors of the destruction of the Mongol invasion. The Mongol invasion has become an increasingly popular topic in historical and archaeological research in general as well. Battlefield research is a branch of archaeology that has gained greater momentum in Hungary in recent years as a result of new technical opportunities. Accurate identification of the Muhi battlefield remains a major challenge despite of the utilization of the most complex research methods, but multidisciplinary research has already yielded several positive results. New sites not included in the public register have been unearthed as parts of the former settlement network. The methodological observations from the research also provide important professional experience for examining the sites of other similar battles.

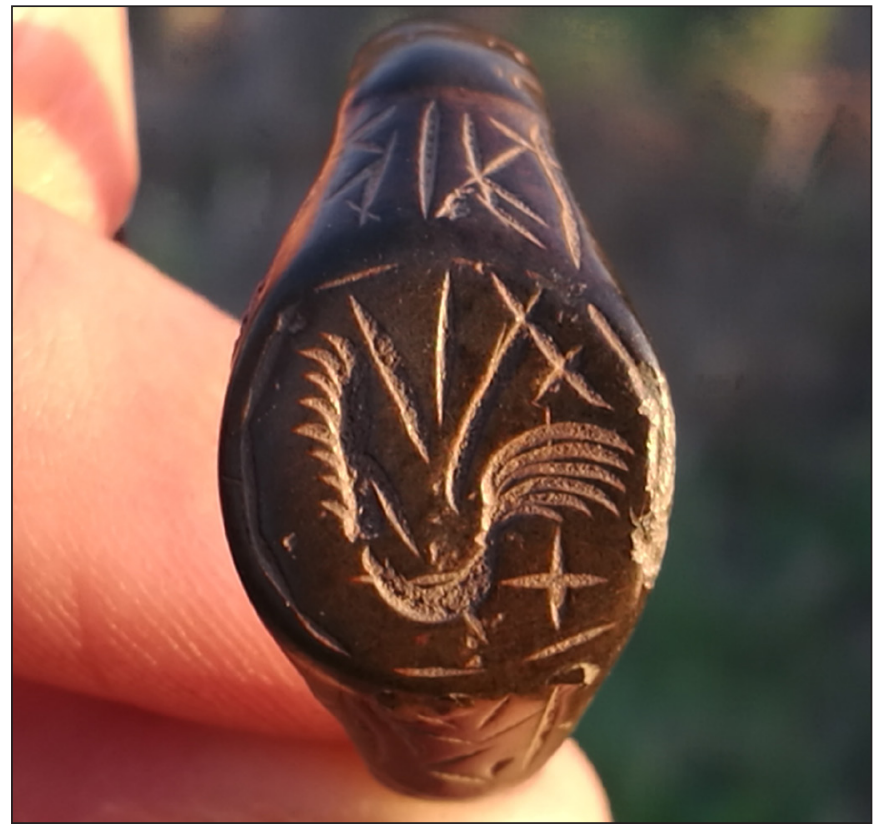

Fig. 9. Ring with incised ornament, brought to light at an identified site of the battle (photo by T. Á. Rácz)

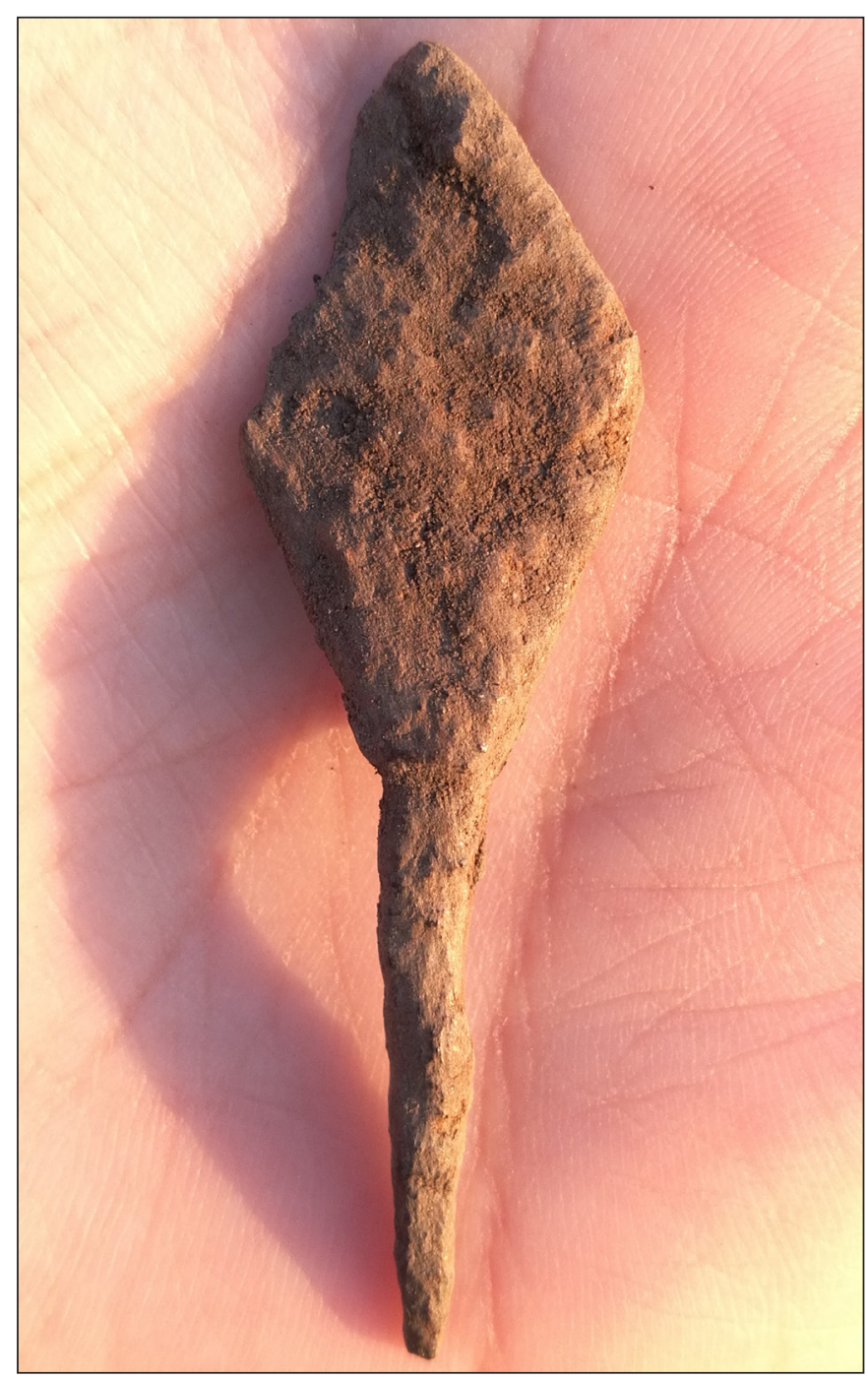

Fig. 10. Rhombus-shaped arrowhead discovered at an identified site of the battle (photo by T. Á. Rácz) 
József Laszlovszky - Tibor Ákos Rácz • Research Using Metal Detectors at the Battlefield of Muhi

BIBLIOGRAPHY

B. Szabó, J. (2019). A muhi csata (1241. április 11.) [The Battle of Muhi (11 April, 1241)]. Korunk 30 (3), $15-25$.

B. Szabó, J., Laszlovszky, J., Nagy, B. \& Uhrin, D. (2020). The Mongol Invasion of Hungary (1241-42) and its Eurasian context. Annual of Medieval Studies at CEU 26 (2020), 223-233.

Bakos, G. (2020). From Metal Detection Field Surveys to Community Archaeology in Borsod-AbaújZemplén County. Hungarian Archaeology 9 (2) [2020 summer], 68-73. https://doi.org/10.36338/ha.2020.2.3

Espenshade, C. T. (2019). Avocational Detectorists and Battlefield Research: Potential Data Biases. In N. Moreira, M. Derderian \& A. Bissonnette (eds.), Fields of Conflict. Conference (2018) Pequot Museum. Conference Proceedings Vol.1. (pp. 43-49). Mashantucket, CT: Pequot Museum and Research Center.

Farkaš, Z. (2006). Stredoveké opevnenie v Stupave, poloha Drači Hrádok (Mittelalterliche Befestigung in Stupava, Flur Dračí hrádok). Zborník Slovenského Národného Múzea C. Archeológia (16), 235-302.

Farkaš, Z. (2015). Stredoveké opevnenie Starý Zamok II pri Pezinku (Die mittelalterliche Befestigung Starý Zámok II bei Pezinok). Zborník Slovenského Národného Múzea C. Archeológia (16), 257-297.

Ferguson, N. (2012). The Battle of Philiphaugh Community Archaeology Project: Final Report. Centre for Battlefield Archaeology, University of Glasgow.

Freeman, P. W. M. \& Pollard, A. (eds.) (2001). Fields of Conflict: Progress and Prospect in Battlefield Archaeology. British Archaeological Reports International Series 958. Oxford: British Archaeological Reports.

Győrfi, Z. (2012). Medieval Weapons from Bistra Mureşului. Marisia - Studii şi materiale, Arheologie $(24 / 25), 117-137$.

Kuśnierz, J. (2005). Militaria z Czermna nad Huczwa. Próba rekonstrukcji sposobu ataku tatarów na gród (w. 1240 r.) na podstawie dotychczasowych badań archeologicznych (Military items from Czermno on the River Huczwa. An attempt at reconstructing the Tartars' attack on the stronghold (in 1240) based on the existing archaeological studies). Acta Militaria Mediaevalia (1), 115-132.

Laszlovszky, József (2013). Tatárjárás és régészet [The Mongol Invasion and Archaeology]. In B. Nagy (ed.), Tatárjárás (pp. 453-468). Budapest: Osiris.

Laszlovszky, J., F. Romhányi, B., Ferenczi, L., Pow, S. \& Pinke, Zs. (2018). Contextualizing the Mongol Invasion of Hungary in 1241-42: Short- and long-term perspectives. Hungarian Historical Review: New Series of Acta Historica Academiae Scientiarium Hungaricae 7 (3), 419-450.

Laszlovszky, J., Pow, S. \& Pusztai, T. (2016). Reconstructing the Battle of Muhi and the Mongol Invasion of Hungary in 1241: New Archaeological and Historical Approaches. Hungarian Archaeology 5 (4) [2016 winter], 29-38.

Négyesi, L. (1997). A muhi csata. 1241. április 11 [The Battle of Muhi. 11 April, 1241]. Hadtörténelmi Közlemények (110), 296-310. 
József Laszlovszky - Tibor Ákos Rácz • Research Using Metal Detectors at the Battlefield of Muhi

Nowakowski, P. A. (2014). Sprawozdanie z badań archeologicznych prowadzonych na terenie Pól Grunwaldu w dniach 14-24.09.2014 r. [Report about the Archaeological Researches executed in the Area of Grunwlad between 14-24 September, 2014]. Nowe Studia Grunwaldzkie 1, 79-87.

Nowakowski, P. A. (2015). Sprawozdanie z badań archeologicznych prowadzonych na terenie Pól Grunwaldu w dniach 15-22.08.2015 r. [Report about the Archaeological Researches executed in the Area of Grunwlad between 15-22 August, 2015]. Nowe Studia Grunwaldzkie 2, 113-139.

Nowakowski, P. A. (2016). Sprawozdanie z badań archeologicznych przeprowadzonych na Polach Grunwaldu w dniach 11-17.09.2016 r. [Report about the Archaeological Researches executed in the Area of Grunwlad between 11-17 September, 2016]. Nowe Studia Grunwaldzkie 3, 39-63.

Nowakowski, P. A. (2017). Sprawozdanie z badań archeologicznych przeprowadzonych na Polach Grunwaldu w dniach 9-17 września 2017 r. [Report about the Archaeological Researches executed in the Area of Grunwlad between 9-17 September, 2017]. Nowe Studia Grunwaldzkie 4, 23-31.

Polgár, B. (2019). Az 1526. évi mohácsi csata régészete: régi eredmények és újabb kutatási perspektívák [The Archaeology of the Battle of Mohács in 1526: Old Results and Newer Perspectives]. In P. Fodor \& Sz. Varga (eds.), Több mint egy csata: Mohács. Az 1526. évi ütközet a magyar tudományos és kulturális emlékezetben (pp. 381-412). Budapest: MTA Bölcsészettudományi Kutatóközpont.

Pollard, T. \& Banks, I. (2010). Now the wars are over: The past, present and future of Scottish battlefields. International Journal of Historical Archaeology 14 (3), 414-441.

Pow, S. \& Laszlovszky, J. (2019). Finding Batu's Hill at Muhi: Liminality between rebellious territory and submissive territory, earth and heaven for a Mongol prince on the eve of battle. Hungarian Historical Review: New Series of Acta Historica Academiae Scientiarium Hungaricae 8 (2), 261-289.

Rácz, T. Á. (2017). Metal detector users affiliated to museums: Building a model of community archaeology in Pest County. Hungarian Archaeology 6 (3) [2017 autumn], 1-8.

Rácz, T. Á. (2019). Közösségi régészet. Egy új kutatási eljárás születése [Community Archaeology. The Birth of a New Research Method]. Múzeumcafé 72 (4), 149-157.

Rosta, Sz. (2018). Egy új lehetőség kapujában - tatárjárás kori védmüvek a Kiskunságban. [In the Gate of a New Opportunity - Protection Devices in Kiskunság during the Mongol Invasion] In D. Mérai et al. (eds.), Genius Loci-Laszlovszky 60 (pp. 186-192). Budapest: Archaeolingua.

Scott, D. D., Fox, R. A., Connor, M. A. \& Harmon, D. (1989). Archaeological Perspectives on the Battle of the Little Bighorn. Norman, OK: University of Oklahoma Press.

Scott, D. D. \& McFeaters, A. P. (2011). The archaeology of Historic Battlefields: A history and theoretical development in conflict archaeology. Journal of Archaeological Research 19 (1), 103-132. https://doi. org/10.1007/s10814-010-9044-8

Sutherland, T. L. \& Holst, M. R. (2005). Battlefield Archaeology -The Archaeology of Ancient and Historical Conflict. British Archaeological Job Resource Guides 8. http://www.bajr.org/BAJRGuides/8.\%20 Battlefield $\% 20$ Archaeology $\% 20 \% 20 \mathrm{~A} \% 20$ Guide $\% 20$ to $\% 20$ the $\% 20$ Archaeology $\% 20$ of $\% 20$ Conflict/ BAJRBattleGuide.pdf (Accessed 17 Dec 2020). 
József Laszlovszky - Tibor Ákos Rácz • Research Using Metal Detectors at the Battlefield of Muhi

Szabó, M., Bertók, G., Gáti, Cs. \& Szajcsán, É. (2016). Mohács Battlefield Survey - The Lessons Learned From The First National Archaeological Metal Detecting Rally. Hungarian Archaeology 5 (2) [2016 summer], 1-8.

Újhelyi, N. (2017). Archaeology and metal detecting in Hungary (2000 to 2014). Annual of Medieval Studies at CEU 23, 187-199.

V. Szabó, G. (2013). Late Bronze Age Stolen. New Data on the Illegal Acquisition and Trade of Bronze Age Artefacts in the Carpathian Basin. In A. Anders \& G. Kulcsár (eds.), Moments in Time. Papers Presented to Pál Raczky on His 60th Birthday (pp. 793-815). Budapest, Ösrégészeti Társaság - Eötvös Loránd University - L'Harmattan.

V. Szabó, G., Czajlik, Z. \& Reményi, L. (2014). Traces of an Iron Age Armed Conflict. Hungarian Archaeology 3 (1) [2014 spring], 1-7.

Wolf M. (2014). Régészeti adatok a muhi csata történetéhez [Archaeological Data for the History of the Battle of Muhi]. In Sz. Rosta \& Gy. V. Székely (eds.), "Carmen miserabile.” A tatárjárás magyarországi emlékei. Tanulmányok Pálóczi Horváth András 70. születésnapja tiszteletére (pp. 69-80). Kecskemét: Kecskeméti Katona József Múzeum. 